\title{
THE CUP AND BAPTISM: METAPHORS OF SERVANT LEADERSHIP IN MARK 10:38-39
}

Mookgo Solomon Kgatle

\section{Introduction}

This chapter is part of the fourth Christian Leadership Conference theme "Metaphors of leadership or leading by metaphors". In the chapter, I present "cup" and "baptism" as metaphors of servant leadership in Mark 10:38-39. A literature review on the two verses, Mark 10:38-39, will assist with an understanding of the key message in the text. I will then explore various possible biblical and metaphorical denotations of the "cup" and "baptism", and apply the implications in Mark 10:38-39 to the matter of servant leadership. The chapter will illustrate that the call by Jesus for his disciples to drink his cup and to be baptised with his baptism is a timely reminder that occupying positions of greatness in the kingdom of God may involve suffering. It is a call for leaders around the world to endure hardship and tribulation with the hope of an eschatological vindication. It is also a call for leaders to embrace a leadership of serving others rather than seeking to attain positions and places of honour. According to Greenleaf (1997:14), servant leaders demand to serve first and to acquire a position later. In other words, they seek primarily to minister and they become great because of their attitude towards serving.

\section{The context of Mark 10:38-39}

Mark 10:38-39 is about Jesus' response to James and John's ${ }^{1}$ request to be seated one on the left and the other on the right in the glory of Jesus (Mk 10:35). Jesus teaches them the true essence of discipleship in response to their misunderstanding of this concept. Johnson opines:

Jesus' teaching on humble service is nowhere better expressed than in Mark 10:38-39, and it is characteristic of Mark that the pattern of discipleship is

\footnotetext{
${ }^{1}$ James and John, the sons of Zebedee, were Galilean fishermen and two of the twelve disciples of Jesus (Mk 1:19-20). James, John, and Simon (Peter) comprise a trio that attained a place of prominence among the disciples of Jesus in Mark. They are often found at the centre of important events, such as the raising of the daughter of Jarius (Mk 5:37), the transfiguration (Mk 9:2), and Jesus' agony in the garden of Gethsemane (Mk 14:3).
} 
service epitomised by Jesus. Jesus is not just an apocalyptic judge but the one who has healed the sick, embraced children and patiently taught his disciples (Johnson 1972:178).

Williamson affirms that Jesus' life was one of service and that his death was for others. The supreme service of Jesus Christ was the voluntary giving of his life as a ransom for many (Williamson 1983:190).

Mark 10:38-39 is about discipleship as self-denying, as self-risking and as service for the redemption of the world. There are two ideas in the text, lordship and service. Seeley says "the two stand in sharp contrast to one another. The tension between the lordship and service gives the passage much of its force. Unlike those who are regarded as ruling over nations, disciples should become servants in order to be first" (Seeley 1993:234).

Another point of discussion arising from the passage is that Jesus teaches his disciples that the places of honour are not his to appoint. In addition, Jesus tells them his expectations of discipleship. They cannot be like the "great ones" of the world, who like to rule over people but need to serve others. According to Geisler (2007:73), the instruction to the disciples is about humility and service. The challenge to the disciples is to a radical and paradoxical form of discipleship called service, of which Jesus is presented as the ultimate example through his suffering and death (Hutchison 2009:54). This re-education on discipleship is particularly emphasised in the central section of the Gospel (Mk 8.22-10.52), with its theme of true discipleship and its use of the suffering Son of Man (Telford 1999:51).

The death of Jesus is not only the supreme example of what it means to be "great" in the kingdom of God. According to Stein, greatness is being a servant and slave to all. Jesus illustrated this great service by giving his life as a ransom and a sacrifice for humanity to receive forgiveness of $\sin$ and overcome death (Stein 2008:489). Jesus illustrates his love and passion for humanity through redemption by his blood on the cross. He demonstrates that discipleship is about saving the lost and healing the sick. Jesus shows his disciples that the essence of discipleship is to lay down one's life, given that it was an example meant to be followed. The point here seems 
to be that "discipleship is a relationship established by the call of Christ and defined by his own faithfulness, not by any merit that can be attributed to the disciples themselves" (Powell 2009:142).

\section{Possible meanings of "cup"}

\subsection{Biblical meanings of "cup"}

In the Old Testament, several scriptures speak about the cup 2 in various meanings. The psalmist speaks of snares, fire and brimstone, and a horrible tempest being rained upon the wicked, and that these tribulations "shall be part of their cup" (Ps 11:6). The psalmist also speaks of the cup of salvation that he uses to call upon the name of the LORD (Ps 116:13). The psalmist further speaks of a cup of joy or salvation (Ps 16:5; 23:5) and a cup of suffering or punishment that God sends to the wicked (Ps 11:6). The metaphor also refers to what God has in store for an individual, whether it is good or bad (Ps 23:5). "Baptism" can also refer to calamity, tribulation and death (Ps 42:7) and both "cup" and "baptism" are symbols of judgement (Ps 75:8).

The Prophet Isaiah refers to the suffering of God's people, which will now be passed to their oppressors (Is 51:71-23 cf Lm 4:21). The prophet exclaims to Jerusalem that this is because they have drunk the cup of the fury and trembling and it has exhausted them (Is 51:17 cf 51:22; Jr 25:15). The Lord uses the cup of trembling to fight anyone who comes against Judah and Jerusalem (Zch 12:2). The Prophet Jeremiah speaks about the "cup of consolation" that serves in the remembering of those who have died. The prophet discourages the taking of this kind of a cup (Jr 16:7). The Prophet Ezekiel attests to the cup of astonishment and desolation that will surprise the daughters of Samaria (Ezk 23:33). Habakkuk speaks of the cup of the Lord's right hand. This cup is able to bring shame on the glory of people (Hab 2:16).

In the New Testament, Jesus asks his disciples if they are ready to drink his cup. Although the disciples answer in the affirmative to Jesus' question, they seem to

\footnotetext{
${ }^{2}$ Потńpıov a cup, a drinking vessel. It is a metaphor for one's lot or experience, whether joyous, or adverse, divine appointments, whether favorable, or unfavorable, relates to a cup that God presents one to drink, a cup of prosperity and adversity.
} 
misunderstand the meaning of drinking the cup of Jesus. Hence, Jesus says to them that while they shall drink the cup, positions in the kingdom on his right and his left are not his to give, but that they are given by the father in heaven (Mt 20:22-23 cf Mk 10:38-39). The cup also appears as a symbol in the supper of the Lord where Jesus took the cup and gave it to his disciples to drink (Mt 26:27 cf Mk 14:23; 1 Cor $10: 16 ; 11: 25-26)$. The cup in the New Testament attests to sorrow and pain in the same way that it does in the Old Testament. Hence, Jesus prays that the cup passes him by, but he also acknowledges that the will of the Father must be done in his life (Mt 26:39; 26:42 cf Mk 14:36; Lk 22:42). This is the cup of the wrath of God. The cup speaks of indignation that makes people remember the Lord (Rev 14:10; 16:19; $17: 4)$

\section{2 "Cup" as a metaphor}

Jesus teaches servant leadership in Mark 10:38-39 through the use of metaphors. One of the metaphors is the cup. The cup offered to James and John is an image for destined suffering (France 2002:416). In Mark's gospel, the cup appears in the context of great suffering in Jesus' prayer at Gethsemane (Mk 14:6). In addition, the "cup" is also a Jewish expression for a share in someone else's fate. The cup itself is a scriptural figure for one's providential portion, or the lot assigned to one by God, whether good or evil (Alexander 1961:291).

Sanner (1979:361) maintains that the cup refers to inward suffering. This usage probably arose from the custom in ancient times that the master of the household distributed to his children and servants an allowance of meat and drink according to their importance. It is the same custom observed for the entertainment of guests (Donahue \& Harrington 2002:311). Nouwen (1996:35) says that Jesus' cup is the cup of sorrow, not just his own sorrow but also the sorrow of humanity. It is the cup of starvation, torture, aloneness, rejection, abandonment, and immense anguish. It is the cup full of bitterness. It is the cup that Isaiah calls "the cup of God's wrath".

Nouwen (1996:50) continues that Jesus' cup is also a cup of joy. Jesus' unconditional acceptance of the will of his father had empowered him to drink his cup, not in passive resignation but with the full knowledge that the hour of his death 
would also be the hour of his glory. His "yes" made his surrender a creative act, an act that could bear much fruit. This reminds us that the cup of sorrow is also the cup of joy and that precisely what causes us sadness can become a fertile ground for gladness. Indeed, we need to care for each other, to give each other strength and consolation. When we fully realise that the cup of sorrow is also the cup of joy, we will be able to drink it. Jesus' cup is also a cup of blessings, according to Nouwen (1996:68). Jesus took upon himself all this suffering and lifted it up on the cross, not as a curse but as a blessing. Jesus made the cup of God's wrath into a cup of blessing. Jesus died for us so that we may live. He poured out his blood for us so that we may find new life. He gave his life away for us so that we can live in communion. He became, for us, food and drink for everlasting life. That is what Jesus meant when he took the cup and said, "This is the new covenant in my blood, poured out for you" (Lk 22:20).

Drinking the cup, as Jesus did, is the way out of $\sin$ and death. It is the way to salvation. It is a hard way, a painful way, a way we want to avoid at all costs. Often it seems an impossible way. Still, unless we are willing to drink our cup, real freedom will elude us. This is not only the freedom that comes after we have completely emptied our cup, but that comes to us every time we drink from the cup of life. Salvation is not only a goal for the afterlife. Salvation is an everyday reality that we can taste here and now (Nouwen 1996:91). The disciples have understood that they are not to seek power or reward in this age, so now they seek it in the age to come! Jesus asks them if they can stand firm in the face of persecution, drink his cup, be baptized with his baptism. They say they can. The disciples do understand that persecution is a consequence of following God's rule now. However, Jesus does not give them what they ask for; persecution in this age brings no reward in the next (Dewey \& Malbon 2009:319).

\section{The possible meanings of "baptism"}

\subsection{Biblical meaning of "baptism"}


Not only did Jesus ask his disciples if they were ready to drink his cup, but he also asked if they were ready for his baptism ${ }^{3}$. The disciples answered yes to both questions. However, I want to reiterate that the disciples of Jesus did not understand the question that Jesus was asking - rather, they were thinking about positions on the left and right of Jesus. Jesus had to explain that these positions were not for sale, but that they would be granted only by the father and only to people for whom such positions were prepared (Mt 20:22-23 cf Mk 10:38-39). Baptism represents a triumph over death: Just as Christ was raised up from the dead by the glory of the Father, even so we also should walk in newness of life ( $\mathrm{Rm} \mathrm{6:4} \mathrm{cf} \mathrm{Col} \mathrm{2:12).} \mathrm{Baptism}$ may also refer to the believer's baptism. In Matthew 28:19-20, Jesus says to his disciples: "Go, and make disciples of all nations, baptising them in the name of the Father and of the Son and of the Holy Spirit, teaching them to observe all things which I commanded you. Behold, I am with you always, even to the end of the age". This baptism is for those who believe and it is baptism through immersion (Mt 3:1617; Jn 3:23; Act 8:38; Rm 6:4). The believer's baptism is different from John's baptism because a person has to repent of his or her sins to experience it (Act 19:15). In this specific context, baptism attests to regeneration $(\mathrm{Rm} \mathrm{6:3-4)}$ and to the remission of sins (Act 2:38).

\section{2 "Baptism" as a metaphor}

Jesus also teaches servant leadership in Mark 10:38-39 by the use of another metaphor, baptism. The narrative context of Mark supposes that Jesus uses baptism to depict the suffering and death into which he is soon to be "plunged" (Thurston 2002:116). Baptism means to be bathed, but it is also a specific reference to ceremonial washing in terms of the law. This definition of baptism relates to the New Testament's water baptism that, in a way, symbolises the washing away of sins

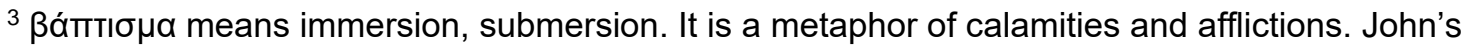
baptism teaches that a purification rite in which persons would confess their sins in order to receive spiritual reformation, obtain pardon for their past sins, and become qualified for the benefits of the Messiah's kingdom, was soon to be set up. This was a valid Christian baptism and the only baptism the apostles received. There is no record anywhere of their ever being re-baptised after Pentecost. Christian baptism - a rite of immersion in water as commanded by Christ, by which one, after confessing sins and professing one's faith in Christ, having been born again by the Holy Spirit unto a new life - identifies publicly with the fellowship of Christ and the church.
} 
(Alexander 1961:291). Baptism refers to agony and overwhelming sorrow or outward persecution and affliction (Sanner 1979:361).

The metaphor of the "baptism" is a parallel thought. Baptism conveys the idea "to identify with", showing Jesus' acceptance of the suffering ahead (Hutchison 2009:62). The baptism that Jesus accepted was not just the water baptism of John the Baptist, but the baptism of fire to which John alluded (Mk 1:8). To "accept baptism" (or "deep water"), the term used in ancient literature for "flood" or "getting soaked", is to accept God's way of suffering. Since Jesus applied the cup uniquely to himself, baptism is best taken here as his submission to the Father's will in facing the cross (Mk 14:36).

The image of baptism reminds the baptised that they have been baptised into the death of Christ. Certainly, James underwent martyrdom (Act 12:2). John's fate, however, is uncertain. Thus, the New Testament alludes to baptism as the meaning of suffering. It is clear that anyone who seeks the prestigious seats of glory is, in fact, asking to take part in Jesus' death. The baptism of Jesus is not as simple a matter as James and John perceive it to be; it is deeper than what they bargain for, and it refers to exceedingly difficult times.

\section{Metaphors of servant leadership}

The term "servant leadership" has, according Kgatle (2017:286), been a trademark of Greenleaf's ${ }^{4}$ since the 1970 s and has become the epitome of the concept. Greenleaf spoke, wrote and lived servant leadership. Greenleaf also emphasised that service to one's followers is a priority that contrasts with personal agendas and power. Becoming a servant leader begins with the natural feeling that one wants to serve. One is then inspired to make a conscious choice towards leadership. A servant leader is sharply different from someone who is a leader first and foremost,

\footnotetext{
${ }^{4}$ Robert K Greenleaf coined and modelled scholarly research of this study in the late seventies. For this reason, servant leadership is now known as his leadership theory and practice. He is also known as the founder of the servant leadership movement and the Greenleaf Centre for Servant Leadership. In his book, Servant Leadership: A journey into the nature of legitimate power and greatness, he concluded that a great leaders are seen as a servants first and that simple fact is the key to their greatness (Greenleaf 1997:7).
} 
perhaps because of a need to assuage an unusual power-drive or to acquire material possessions (Greenleaf 1997:13). Servant leadership, in the words of Northouse (2004:2), is not about position but manifests in terms of the power relationship that exists between leaders and followers.

What is new in this chapter is how the concept of servant leadership relates to the concepts of "cup" and "baptism". "Cup" and "baptism" are metaphors for servant leadership because suffering is the cost of participating in God's kingdom (Burge \& Hill 2012:1036). Jesus demonstrates that servant leadership is about suffering and sacrifice (Kgatle 2016:104). Both baptism and the cup remind us forcibly, by their symbolism, of the cost of following Christ; the servant must be like his Master. The cup of suffering and the baptism - both of death and of empowerment for mission are the means of fellowshipping with him and are the only way to follow him (Hooker 1991:246). When applied to servant leadership, the use of both cup and baptism in Mark 10:39 suggest that leaders should participate morally in Jesus' passion. They should do so as an expression of sharing in his fate (William 1984:379).

Servant leaders should be willing to suffer with Jesus, or to share in his suffering on the cross of Calvary. Servant leaders should lead the same way that Jesus led his disciples. What this means is that to drink the cup is to partake in the suffering of Jesus. To be baptised in His baptism is to sink deep into his suffering. If baptism means immersion, then to be baptised into his suffering means to accept an immersion into the trials and tribulations of Jesus. Servant leaders in our time should not be interested only in positions of leadership but should be prepared to take part in Jesus' suffering too.

The call for James and John to take part in drinking Jesus' cup and to be baptised in his baptism is a call to a kind of servant leadership that sees the person concerned sharing the suffering of Jesus before occupying any position. Servant leadership in this context is "suffering servanthood" precisely because Jesus' cross defines the meaning of service (Tan 2009:88). The cross-shaped pattern of servant leadership is every bit as radical as it was on Golgotha. In today's culture, many leaders still gravitate toward patterns of leadership oriented along the lines of dominance, 
control, and power. This happens when Christians find themselves pressured to adapt to the world's mould - or when they deliberately adopt the world's way of doing things.

Servant leaders should be willing to go through difficult times and tribulations in life. A servant leader does not live to please others, but to please God. This means that servant leadership is a willingness to live a life of pleasing God at all times. Such willingness may result in the servant leader experiencing persecution from a number of directions. Suffering does not only mean a life of poverty, sickness, or death. It also implies persecution because the leader follows Jesus. Leaders should align themselves to God's plan and programme for their lives and should identify with Jesus' suffering.

The cup and baptism are not only symbols of suffering but of eschatological vindication. In counterpoint to the persecution and trials that the servant leader will experience, there will also be the reward of serving others. The cup and baptism refer not only to sorrow but also to the eschatological vindication that Christ will ultimately grant to all believers and his church. The main purpose of the cup and the baptism of Jesus is the salvation of his people. Anyone who is willing to share the cup and baptism of Jesus will receive salvation of their own soul.

\section{Conclusion}

This chapter has explored various possible biblical and metaphorical denotations of the "cup" and "baptism" referred to in Mark 10:38-39. It has applied the various possible implications of these terms to servant leadership in the contemporary world. Furthermore, the chapter has demonstrated that "cup" and "baptism" are metaphors for servant leadership. It makes a call to leaders to apply the metaphors of the "cup" and "baptism" in servant leadership, calling them to endure hardship and tribulation in their leadership. It is a call for leaders to remember that participating in the fate of Jesus has the promise of eschatological vindication and reward for faithful service.

\section{Bibliography}


Alexander, J.A. 1961. The gospel according to Mark. London: Banner of Trust. Burge, G.M. \& Hill, A.E. 2012. The Baker illustrated Bible commentary. Grand Rapids, Michigan: Baker Books.

Dewey, J. \& Malbon, E.S. 2009. Mark, in D.L. Petersen \& G.R. O’Day (eds):

Theological Bible commentary. Westminster: John Knox Press.

Donahue, J.R. \& Harrington, D.J. (eds) 2002. The Gospel of Mark. Collegeville, Minnesota: Liturgical Press.

France, R.T. 2002. The Gospel of Mark. Commentary on the Greek text. Grand Rapids, Michigan: William B. Eerdmans.

Geisler, G.L. 2007. A popular survey of the New Testament. Grand Rapids, Michigan: Baker Books.

Greenleaf, R.K. 1997. Servant Leadership. A journey into the nature of legitimate power and greatness. New York: Paulist Press.

Hooker, M.D. 1991. The Gospel according to Saint Mark. London: Hendrickson.

Hutchison, D. 2009. Servanthood. Jesus' countercultural call to Christian leaders. Bibliotheca Sacra 166(1), 53-69.

Johnson, S.E. 1972. The Gospel according to Saint Mark. 2nd ed. New York: Adam \& Charles Black.

Kgatle, M.S. 2016. Servant leadership in Mark 10:35-45 applied to African Pentecostal Christianity. Doctoral dissertation, University of Pretoria.

Kgatle, M.S. 2017. Servant Leadership: Son of Man as Minister and Life Giver in Mark 10.45. Journal of Pentecostal Theology 26(2), 286-298.

Northouse, P.G. 2004. Leadership. Theory and practice. 3rd ed. Thousand Oaks, CA: Sage.

Nouwen, H.J. 1996. Can you drink the cup? Notre Dame, Indiana: Ave Maria Press.

Powell, M.A. 2009. Introducing the New Testament. A historical, literary, and theological survey. Grand Rapids, Michigan: Baker Academic.

Sanner, A.E. 1979. The Gospel according to Mark. Kansas City: Beacon Hill.

Seeley, D. 1993. Rulership and Service in Mark 10:41-45. Novum Testamentum 35(3), 234-250.

Stein, R.H. 2008. Mark. Louisville, Kentucky: Baker academic. 
Tan, S. 2009. The primacy of servanthood, in E.O. Jacobsen (ed): The three tasks of leadership. Worldly wisdom, pp. 77-90, William B Eerdmans, Grand Rapids Michigan.

Telford, W.R. 1999. The theology of the Gospel of Mark. Cambridge: Cambridge University Press (New Testament Theology). doi: 10.1017/CBO9781139163750.

Thurston, B.B. 2002. Preaching Mark. Minneapolis: Fortress Press.

Williamson, L.R. 1983. Interpretation. A Bible commentary for teaching and preaching. Atlanta: John Knox. 